\title{
Current overview on the study of bacteria in the rhizosphere by modern molecular techniques: a mini-review
}

\author{
M. L. $\operatorname{Lagos}^{1}$, F. Maruyama ${ }^{2}$, P. Nannipieri ${ }^{3}$, M.L. Mora ${ }^{4}$, A. Ogram5 ${ }^{5}$ M.A. Jorquera ${ }^{4 *}$

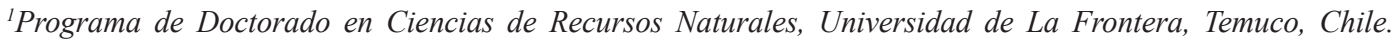 \\ ${ }^{2}$ Section of Microbiology, Graduate School of Medicine, Kyoto University, Yoshida-Konoe-cho, Sakyo-ku, \\ Kyoto 606-8501, Japan. Dipartimento della Scienza del Suolo e Nutrizione della Pianta, Universita' degli \\ Studi di Firenze, 50144 Firenze, Italy ${ }^{4}$ Scientific and Technological Bioresource Nucleus, Universidad de \\ La Frontera, Temuco, Chile. 5 Soil and Water Science Department, University of Florida, Gainesville, 2181 \\ McCarty Hall, PO Box 110290, Florida 32611,USA. *Corresponding Author:milko.jorquera@ufrontera.cl
}

\begin{abstract}
The rhizosphere (soil zone influenced by roots) is a complex environment that harbors diverse bacterial populations, which have an important role in biogeochemical cycling of organic matter and mineral nutrients. Nevertheless, our knowledge of the ecology and role of these bacteria in the rhizosphere is very limited, particularly regarding how indigenous bacteria are able to communicate, colonize root environments, and compete along the rhizosphere microsites. In recent decades, the development and improvement of molecular techniques have provided more accurate knowledge of bacteria in their natural environment, refining microbial ecology and generating new questions about the roles and functions of bacteria in the rhizosphere. Recently, advances insoil post-genomic techniques (metagenomics, metaproteomics and metatranscriptomics) are being applied to improve our understanding of the microbial communities at a higher resolution. Moreover, advantages and limitations of classical and post-genomic techniques must be considered when studying bacteria in the rhizosphere. This review provides an overview of the current knowledgeon the study of bacterial community in the rhizosphere by using modern molecular techniques, describing the bias of classical molecular techniques, next generation sequencing platforms and post-genomics techniques.
\end{abstract}

Keywords: Microbial ecology, molecular techniques, rhizosphere, next-generation sequencing 


\section{Introduction}

The rhizosphere, is defined as the soil zone under the influence of plant roots, a site of high microbial activity, characterized by a great array of complex and dynamic physical, chemical and biological interactions. In the rhizosphere, microorganisms have an important role in the organic matter transformations and biogeochemical cycles of plant nutrients. In this context, a substantial number of bacterial species interact with their host plants and may exert beneficial effects on plant growth, plant nutrition and disease suppression (Avis et al., 2008, Pii et al., 2015). Thus, numerous studies have been devoted to isolate and describe the activities of diverse plant growth-promoting rhizobacteria (PGPR). Among the main functions attributed to PGPR are: biological $\mathrm{N}_{2}$ fixation, phytopathogen biocontrol, phosphate solubilization, production of phytohormones and enzymes, among others. Nowadays, PGPR represent an attractive alternative for chemical fertilizers as biofertilizers, phytostimulators, rhizoremediators and phytopathogen biocontrol agents (Lugtenberg and Kamilova, 2009). Despite the perception that PGPR are considered as not dangerous to the environment, their mass application in agriculture have been limited due to their low efficiency in field-level applications (Babalola, 2010). There is still a lack of information on PGPR ecology (diversity, competence, distribution, communication, etc.) in the rhizosphere (Compant et al., 2005; Lambers et al., 2009; Singh et al., 2011); however, a considerable interest has been generated in their study and potential use in crop production around the world (Morrisey et al., 2004).
Currently, it is recognized that the rhizosphere microbiome harbors thousands of different bacterial, archaeal, viruses, fungal and other eukaryotic taxa. A gram of rhizosphere soil might contain around 109 microbial units and 106 distinct taxa (Torsvik et al., 2002; Curtis and Sloan, 2005). The use of molecular techniques have allowed the characterization of unculturable organisms at a level never seen before, since only $1 \%$ of soil microorganism have actually been cultured (Ver Berkmoes et al., 2009; van Elsas and Boersma, 2011). Molecular techniques based on DNA analyses provide important tools to evaluate bacterial community composition, identifying the abundance of genes that could be involved in rhizosphere processes. With the advent of next generation sequencing technologies (such as Roche 454 and Illumina platforms), it has become possible to characterize the composition and activity of bacteria at much higher resolution than before. Metagenomics (Handelsman et al., 1998; Myrol and Nannipieri, 2014) approaches can allow characterization ofthe unknown genomes of unculturable bacteria with the probability of finding novel microbial products (antibiotics, enzymes, anti-cancinogenics, etc.) (Nannipieri et al., 2008). These high resolution analyses of the taxonomic composition of rhizosphere soil provide baseline information on the specific microbiome members living in rhizosphere environments. In addition, we can thereafter infer the community composition at specific root zones, and their functional relationships with plant growth, nutrient uptake, and plant health. Moreover, both RNA and proteins (proteomics) can provide some information on 
gene activity, such as metatranscriptomics (total RNA from all bacterial communities of rhizosphere soils) inferring soil-microbial functionality (Bastida et al., 2009).

This review provides an overview of the current knowledge on bacterial community in the rhizosphere by using modern molecular techniques, describing the bias of classical molecular techniques, next generation sequencing platforms and post-genomics techniques.

\section{Ecology of bacteria in the rhizosphere}

\subsection{Abundance and diversity}

The rhizosphere harbors a wide variety of bacteria species, and the compositions of bacterial communities differ according to root zone, plant species, plant phenological phase, stress and disease events (Rovira, 1965; Hinsinger et al., 2009; Marschner et al., 2011). Dominant bacterial phyla are members of the classes Proteobacteria, Firmicutes, Actinobacteria, Bacteroidetes and Acidobacteria in the rhizosphere of sugarcane, pea native hardwood forest and conifer plantations (Mendes et al., 2011; Weinert et al., 2011; Yang et al., 2012). Among them, Proteobacteria are considered to be the most abundant bacterial group in the rhizosphere due to their ability to respond to labile $\mathrm{C}$ sources, showing fast growth and adaptation to the diverse plant rhizospheres (Bulgarelli et al., 2013; Chaparro et al., 2014; Peiffer et al., 2013). Proteobacteria is followed by Acidobacteria, which have been attributed an important role in the $\mathrm{C}$ cycle in soils due to their ability to degrade cellulose and lignin (Ward et al. 2009). In relation to Actinobacteria, they have been associated with disease suppressive soils and their ability to increase root nodulation and promote the growth of plants (Mendes et al., 2011; Tokala et al., 2002).

An important bacterial group in the rhizosphere isdefined as PGPR, which are able to promote the growth, nutrient uptake and pathogen biocontrol in plants (Avis et al., 2008; Mendes et al., 2011). According to the current GenBank database from National Center for Biotechnology Information (NCBI), the most abundant groups of bacteria which potentially can promote plant growth are Actinobacteria, Firmicutes, Proteobacteria (Alphaproteobacteria, Betaproteobacteria, Gammaproteobacteria) and Bacteroidetes (Figure 1), and particularly the genera Rhizobium, Azospirillum, Burkholderia, Pseudomonas and Enterobacter. Other bacterial groups reported in the rhizosphere are Verrumicrobia, Sphingobacteria, Flavobacteria, Deinococcus, Fusobacteria, and Epsilonproteobacteria. These bacterial groups are not commonly observed as dominant groups and/ or PGPR in the rhizosphere, although this may be due to our limited knowledge of their taxonomy and functional gene sequences. It is also possible the presence of low abundance bacterial group with specific metabolic capabilities and/or adapted to the characteristic of specific plant species rhizosphere, which make that process of soil DNA extraction to be insufficient to be detected. In addition, studies have described the influence of agriculture practices and soil $\mathrm{pH}$ on bacterial community composition (Cheng et al., 2010; Jorquera et al., 2014; Pisa et al., 2011; Malik et al., 2013; Chen et al., 2013; Nguyen et al., 2013), as well as the occurrence of bacteria species having dependence on other rhizosphere microorganisms for their own growth (Hirsch et al., 2010). 


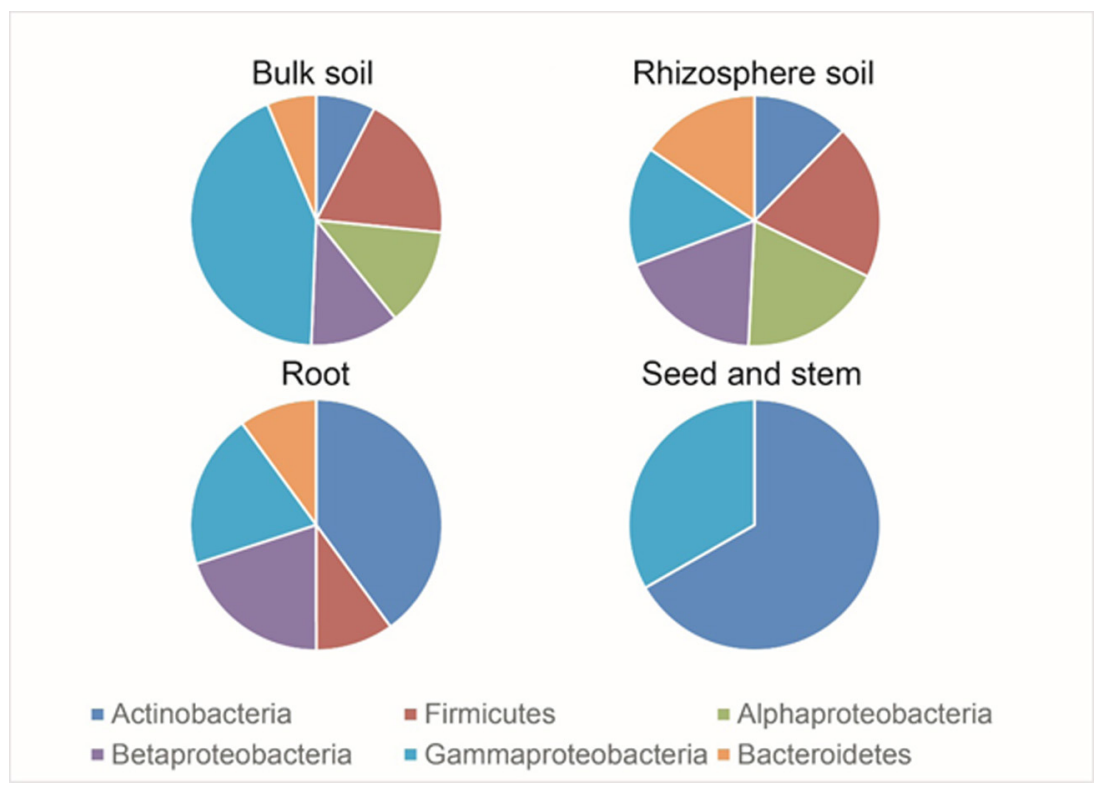

Figure 1.Taxonomic affiliation of 157 entries of plant growth-promoting rhizobacteria (PGPR) in GenBank database in relation to soils (bulk and rhizosphere) and plant tissues (root, seed and stem).

\subsection{Colonization and competence}

It is known that root exudates released by plants into the rhizosphere are used by bacteria as nutrient sources regulating their activities and growth. Root exudates include the releasing of ions, oxygen, water, and organic compounds, such as sugars, organic acids, amino acids, enzymes, growth factors and others (Marschner et al., 2004; Bais et al., 2004; Bertin et al., 2003; Uren, 2000). Lugtenberg et al. (1999; 2001) demonstrated that sugars and organic acids are important for tomato root colonization by bacteria and fungi. In contrast, Karlsson et al. (2012) showed that archaeal abundance was decreased by root exudates, probably as result of their lower growth rates and competitiveness compared with bacteria and fungi. The colonization of rhi- zosphere by bacteria also depend on their motility (Martínez-Granero et al., 2006; Raaijmakers et al., 2009; Capdevila et al., 2004), availability of inorganic compounds ( $\mathrm{P}$ and $\mathrm{Fe}$ ) (Raaijmaker et al., 1995; Yang and Crowley, 2000; Marschner et al., 2004; 2011) and production of antibiotics (Raaijmaker et al., 1995; Doornbos et al.,2012). In this context, Pseudomonas fluorescens strain F113 has been used as model microorganisms for studying the root colonization, motility and competence ofthe indigenous microorganisms of the rhizosphere. Thus, Capdevila et al. (2004) revealed that the motility is essential for root colonization, and that non-motile mutant strains were displaced from the root tip of alfalfa when competed with the wild-type strain. Hyper-motile mutant strains showed a higher colonization in distal parts of the alfalfa root. Plants also can 
influence microbial competition by root exudation. For example, white lupins (Lupinus albus L.) acidifies the rhizosphere by releasing protons from roots, and thus reducing bacteria growth, or they may excrete isoflavonoids, chitinase and glucanases against phatogenic fungi (Weisskopf et al., 2006).

\subsection{Distribution along the rhizosphere micro-} sites

The abundances, diversities and activities of microorganisms differ along the rhizosphere microsites, depending on depletion/availability of nutrients caused by root exudation and competition between microorganisms. It has been described that greater numbers of bacteria occur around the root tip zone (where the highest sucrose or tryptophan exudation occurs), whereas the lower bacterial abundance occurs around the mature root zone (Jaeger et al., 1999). Cellular death with subsequent cell lysis also releases debris which can be used as energy sources for microorganism to survive in the rhizosphere (Watt et al., 2006). Bacterial compositions also depend on soil type, plant species, plant growth seasons and climate conditions. Models of plant-bacteria interactions in different root zones have been proposed (Jaeger et al., 1999; Marschner et al., 2011; Yang and Crowley, 2000). These models support that root exudates are released in a differentiated manner along the root, resulting in a heterogeneous distribution of bacterial communities along root zones (Figure 2). In root tips and the proximal elongation root zone, the exudation rates are high and colonizers use easily metabolizable sugars and organic acids. In contrast, exudation rates and microbial densities are lower in root hair zones. In the mature root zones, the bacterial growth is lower due to low metabolizable C input (Marschner et al., 2011). In addition, we also may suppose that some bacterial populations are unique and have adapted to the rhizosphere by using specific compounds secreted from roots, and that the plant itself interferes with the associated bacterial community independent from soil type (deCampos et al., 2013).

\subsection{Cell-to-cell communication}

The cell-to-cell communication between bacteria in the environment is relevant due to its role inregulating vital functions, biofilm formation, virulence, symbiosis, extracellular enzyme production, antibiotic production, DNA transfer, etc. (Elasri et al., 2001; Raina et al., 2009; DeAngelis et al., 2007). The modes of signal transduction in prokaryotes linking environmental signals to cellular responses are mainly attributed to one-component and two-component systems (Ulrich et al., 2005). In general, soil bacteria can sense the presence of complex molecular exudates through a membrane-bound sensor histidine protein kinase (Fauren et al., 2009). For example, in many Gram-negative bacteria, the beneficial or pathogenic interactions with their host plant are influenced by a GacS sensor kinase and GacA transcription factor (GacS/GacA). This two-component system recognizes environmental signals involved in pathogenicity to plants (Heeb and Haas, 2001). On the other hand, anone-component system implicated in communication of the plant is NodD proteins in Sinorhizobium meliloti that perceives flavonoids and activates expression of nodulation (nod) genes, which are required for symbiotic development in alfalfa (Peck et al., 2006). 


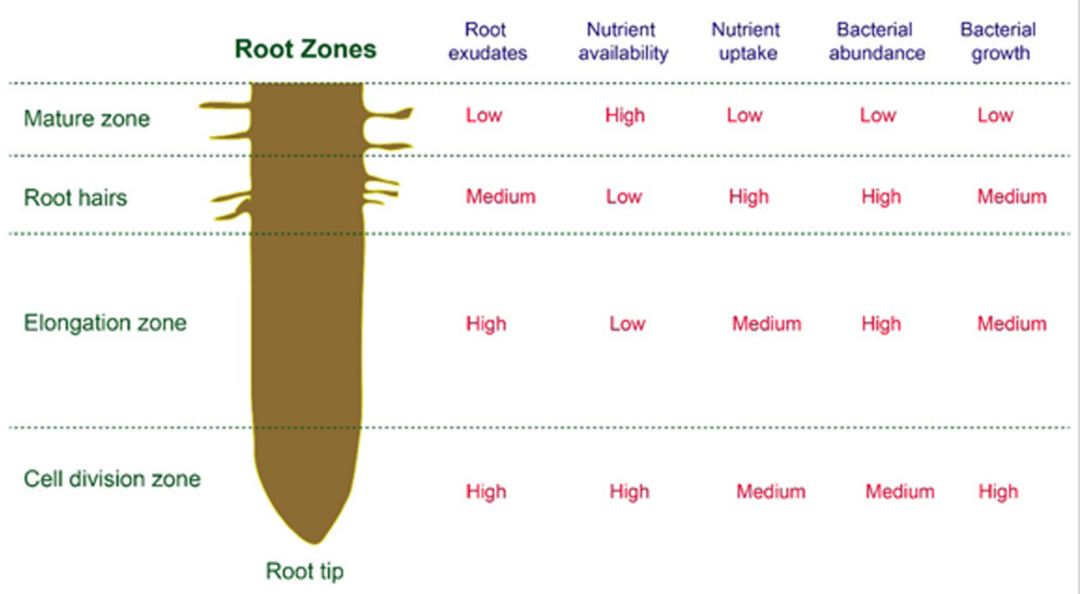

Figure 2. Plant and bacteria properties in different root zones according to models proposed (Jaeger et al., 1999; Marschner et al., 2011; Yang and Crowley, 2000)

The cell-to-cell communication in bacteria may involve quorum sensing (QS), where acylhomoserine lactone (AHL) and compounds Nacylated derivatives of $\mathrm{L}$-homoserine lactone (acyl-HSL) are the main signaling molecules produced by Gram-negative bacteria, and are released to the environment in order to reflecttheir population density. Cha et al. (1998) showed that QS systems mediated by AHLs were 10-fold higher in the rhizosphere than bulk soil, explained by high abundance of bacterial populations in the rhizosphere. Another study revealed that Burkholderia graminis strains M12 and M14, plant growth-promoting rhizobacteria, can produce AHLs that induce protection against salt stress in tomato plants (Barriuso et al., 2008). In Gram-positive bacteria, cell-to-cell communication is controlled by a two-component signal-transduction mechanisms (histidine kinase), releasing oligopeptides in response to changes in cell density (Raina et al., 2009).
Finally, it was postulated that our knowledge of cell-to-cell communication in bacteria could allow us to decipher how stable communities of PGPR can be promoted in the plant rhizosphere (Hirsch et al., 2003), involving further investigations focused on identification of AHLs produced by PGPR (Barriuso et al., 2008) and used as biosensors to understand how these molecules are involved in the diverse rhizosphere processes.

\section{Classical molecular techniques in the study of bacteria in the rhizosphere}

During the last few decades, a wide variety of molecular techniques have been developed and used as valuable tools for the study of diversity and function of bacteria in the rhizosphere (Hill et al., 2000). However, the biases of each molecular technique must be considered and evaluated during their application in the study of bacteria in the rhizosphere. 


\subsection{Fingerprinting techniques}

PCR-based fingerprinting techniques, such as terminal restriction fragment length polymorphism (T-RFLP), denaturing gradient gel electrophoresis (DGGE) and single strand conformation polymorphism (SSCP), have been widely used in the study of bacterial communities in the rhizosphere (Berlec, 2012; Ascher et al., 2011). However, they determine only dominant bacterial populations within the communities, and may consider both active and inactive bacterial populations (van Elsas and Boersma, 2011). Smalla et al. (2007) compared bacterial diversities from several soils and found that T-RFLP was less efficient in assessing bacterial diversity in soil than DGGE, but T-RFLP yielded more reproducible results for comparing large numbers of samples. In general, fingerprinting techniques rely onthe amplification of $16 \mathrm{~S}$ rRNA gene fragments by PCR, but $16 \mathrm{~S}$ rRNA gene copy number per genome vary from 1 up to 15 or more copies depending on the bacterial species. The numbers of rRNA gene copies are related to the life strategy of bacteria; taxa with low copy numbers and inhabit low nutrient environment (oligotrophic) (Větrovský and Baldrian, 2013; Kang et al., 2010).

\subsection{Quantitative PCR ( $q P C R)$ and gene expression}

The qPCR is a molecular technique widely used for detection and quantification of specific genes and their expression from DNA and RNA samples from various environments (Deepak et al., 2007). It is a sensitive technique allowing detection of the signal produced by DNA fragment amplification in real time during each cycle of the PCR reaction. The limitations of real-time
PCR are related to primer specificity, amplification efficiency, and the concentration of RNA in rhizosphere sample, which may be too low for accurate detection (Marschner et al., 2011). However, this technique can provide important insight into the distribution of specific bacterial genes in the rhizosphere and bulk soils (van Elsas and Boersma, 2011, Sørensen et al., 2009), because it is not only used to detect and quantify 16S rRNA genes but also functional genes involved in relevant processes in the rhizosphere, such as nutrient cycling and phytopathogen biocontrol.

The study of gene expression in the rhizosphere soil is still limited (Nannipieri et al., 2008). The majority of previous studies focused on gene expression of Pseudomonas species used as a model to study plant-bacteria interaction in the rhizosphere. Barret et al. (2011) developed a list of 13 bacterial genes of Pseudomonas spp. induced in the rhizosphere in response to root exudates. These genes have functions in metabolism, motility, signal transduction, and unknown functions. Few studies have evaluated the gene expression in the rhizosphere soil. Some examples are: hydrogen cyanide $(\mathrm{HCN})$ induces gene expression in the rhizosphere strawberry of a plant pathogen Verticillium dahlia (Decoste et al., 2010), gene expression of Metarhizium anisopliae that are induced by bean root exudates (Pava-Ripoll et al., 2011), expression of nifH genes by diazotrophic bacteria in the Spartina alterniflora rhizosphere (Brown et al., 2003), betapropeller phytase gene expression in Bacillus sp. strain MQH15 in ryegrass rhizosphere (Jorquera et al., 2013), and quantification and characterization of genotypes of Pseudomonas fluorescens in rhizosphere soil based on 2,4-diacetylphloroglucinol (2,4-DAPG) genes (Mavrodi et al., 2007). 


\subsection{Microarray and transcriptome}

The analysis of transcriptome profiles of rhizosphere strains by microarrays can give information on gene expression involved in the synthesis of several signals to control the bacterial activity in the rhizosphere (Wu et al., 2011). Tremblay and Déziel (2010) analyzed transcript profiles related to motility in Pseudomonas aeruginosa, a ubiquitous Gram-negative bacterium, by GeneChip ${ }^{\circledR}$ microarray. The results showed that swarming colonies displayed general down-regulation of genes associated with virulence and up-regulation of genes involved in energy metabolism. Van Puyvelde et al. (2011) studied the transcriptome of Azospirillum brasilense demonstrating that auxin indole-3-acetic acid is a signal molecule affecting its arsenal of transport proteins and cell surface proteins. However, microarray analysis relies on known genes from bacterial species; however, unknown genes are not detected. Therefore, this technique cannot provide information on the distribution and activities of unknown bacterial genes in the environment (van Elsas and Boersma, 2011).

In this context, Shidore et al. (2012) analyzed the transcript profiles of Azoarcus sp. strain BH72, an endohpytic strain, exposed to root exudates released by Oryza sativa. The microarray analysis showed $2.4 \%$ and $2.0 \%$ of genes up-regulated and down-regulated, respectively; however, modulated gene expression included a few whose involvement in plantmicroorganisms interaction had already been established, whereas a large fraction comprised of genes encoding proteins with putative or unknown functions.

\subsection{Biosensors}

Biosensors are defined as bacterial cells harboring a reporter gene, which is usually a fluorescence marker such as a green fluorescent protein (GFP) cassette expression (Sørensen et al., 2009). This system allows detection of activity and colonization of bacteria at the single cell level in rhizosphere microsites by epifluorescent and confocal microscopy. Germaine et al. (2004) and Götz et al. (2006) successfully introduced GFP-tagged plasmids to localize and monitor the rhizosphere colonization of Pseudomonas putida strain PRD16, Enterobacter cowanii strain PRF116 and endophytic bacterial strains. Recently, Weyens et al. (2012) investigated the colonization and its capacity to promote plant growth by endophytic $P$. putida strain W619 with insertion of GFP-labelled, concluding that it did not promote growth. However, a limited number of reporter genes are available, high background fluorescence can limit detection, and the performance of biosensors can be variable depending on manipulation and sample preparation (Marschner et al., 2011).

\subsection{Proteomics}

Proteomics, defined as the entire protein complement expressed by a genome or by a cell, can be used for evaluating expression and localization of proteins, as well as for analysis of post-translational modifications (Wilkins et al., 1995). However, the extraction of intracellular proteins from soil is a methodological challenge, due to the stability of proteins (protected against proteolysis) and that they may be strongly adsorbed onto soil minerals or co-purify with humic acids 
or soil colloids that will interfere with analysis (Nannipieri, 2006, Arenella et al., 2014). According to Nannipieri (2006), intracellular protein- $\mathrm{N}$ that is the product of microbial activity accounts for an average of only $4 \%$ of the soil total $\mathrm{N}$, whereas a value ranging from 30 to $50 \%$ is due to protein-N stabilized by surface-reactive particles. Therefore, the characterization of intracellular proteins should give insight into microbial functioning of the rhizosphere soil at the sampling time, whereas the characterization of the extracellular stabilized proteins should give indication on past microbial events. Keiblinger et al. (2012) compared four proteins extraction methods in two soils, the method with sodium dodecyl sulfate-phenol gave the highest yield. Recent studies have indicated that proteins associated with metabolic functions such as carbohydrate catabolism and energy production, lipid andaminoacids biosynthesis, signal transduction, and membrane transport are the most abundant in rhizospheres and agricultural, potting, and forest soils (Damon et al., 2012; Wu et al., 2011; Lin et al., 2013). Usually, bacterial proteomics analyses are conducted by $2-$ dimensional polyacrylamide gel electrophoresis (2D-PAGE), 2D-difference gel electrophoresis (DIGE), and mass spectrometry (MS) for investigating expression gene detection involved between plant-pathogen, nitrogen-fixing bacteria in legumes and endosymbiotic interactions (Bestel-Corre et al., 2004; Cheng et al., 2010; VerBerkmoes et al., 2009). Another technique for the study ofthe ecologyin rhizosphere bacteria is SIP (stable isotope probing)-protein technique with ${ }^{13} \mathrm{C}$ or ${ }^{15} \mathrm{~N}$ that can be used for identifying bacterial populations involved in metabolic or biogeochemical processes in the bulk and rhizosphere soils (Bastida et al., 2009).

\section{Post-genomic techniques in the study of bacteria in the rhizosphere}

Currently, it is assumed that the development and improvement of techniques such as metagenomics, metaproteomics, and metatranscriptomics, will provide more accurate evaluation of the activities and compositions of microbial communities in rhizospheres than classical molecular techniques, generating new questions about the roles and functions of these microbial communities (Hirsch et al., 2010; Sørensen et al., 2009).

\subsection{Metagenomics}

In order to study and evaluate the richness, distribution and activity of microbial communities in bulk and rhizosphere soils, it is important to understand the ecological functions of each species. Modern molecular techniques have shown that bacterial diversity of bulk and rhizosphere soil is much greater than was predicted. Soil metagenome study of 16S rRNA gene and ITS1 region using next generation sequencing or second-generation sequencing technologies (Niedringhaus et al., 2011) have revealed that 1 g soil sample maycontain 33,346 bacterial and archaeal OTUs (Mendes et al. 2011), 3,320 fungal OTUs (Schmidt et al., 2013), 145 to 200 of fungal OTUs (Xu et al., 2012), and 300 archaea OTUs (Pires et al., 2012). Both Roche 454 and Illumina platforms have been used to address the bulk and rhizosphere soils (Table 1). Roche 454 pyrosequencing platform produces long read length ( $<450 \mathrm{bp})$ and high consensus accuracy more than Illumina platform (Unno, 2014). Uroz et al. (2010) by 454 pyrosequencing compared the bacterial diversity of oak rhizosphere and bulk soil, finding that Proteobacteria, Acido- 
bacteria, Actinobacteria, Bacteroidetes were the dominant taxa. Recently, Lagos et al. (2014) characterized the composition of bacterial communities of rhizosphere microsites (root tips and mature root zones) of Lolium perenne and found that Proteobacteria, Actinobacteria and Acido- bacteria were the dominant phyla. Similarly, Sun et al. (2014) characterized the diversity of bacterial communities of apple rhizosphere by Illumina sequencer and found that Proteobacteria, Acidobacteria, Bacteroidetes, Gematimonadates and Actinobacteria were the dominant groups.

Table 1. A summary of next generation sequencing platforms used in bacterial ecology studies

\begin{tabular}{|c|c|c|c|c|c|c|}
\hline $\begin{array}{l}\text { Company/ } \\
\text { Platforms }\end{array}$ & $\begin{array}{l}\text { Read } \\
\text { lengh (bp) }\end{array}$ & Run time & $\begin{array}{l}\text { Sequencing } \\
\text { principle }\end{array}$ & $\begin{array}{l}\text { Library } \\
\text { amplification }\end{array}$ & Signal detection & System overview \\
\hline \multicolumn{7}{|l|}{ Roche } \\
\hline $\begin{array}{l}454 \text { GS FLX Titanium XL+ } \\
454 \text { GS FLX Titanium }\end{array}$ & $\begin{array}{l}\sim 1000 \\
\sim 600\end{array}$ & $23 \mathrm{~h}$ & \multirow[t]{3}{*}{$\begin{array}{l}\text { Pyrosequencing by } \\
\text { synthesis }\end{array}$} & \multirow[t]{3}{*}{$\begin{array}{l}\text { Emulsion PCR } \\
\text { on microbeads }\end{array}$} & \multirow[t]{3}{*}{$\begin{array}{l}\text { Optical detection of light } \\
\text { from pyrophosphate release } \\
\text { on nucleotide incorporation }\end{array}$} & \multirow[t]{3}{*}{$\begin{array}{l}\text { Single gene; genome and } \\
\text { transcriptome sequencing }\end{array}$} \\
\hline 454 GS Junior & $\sim 400$ & $10 \mathrm{~h}$ & & & & \\
\hline 454 GS Junior+ & $\sim 700$ & $18 \mathrm{~h}$ & & & & \\
\hline \multicolumn{7}{|l|}{ Illumina } \\
\hline \multirow[t]{2}{*}{ Miseq } & $\sim 300$ & $\sim 5-55 \mathrm{~h}$ & \multirow{4}{*}{$\begin{array}{l}\text { Reversible } \\
\text { terminator } \\
\text { sequencing by } \\
\text { synthesis }\end{array}$} & \multirow{4}{*}{$\begin{array}{l}\text { Bridge PCR on } \\
\text { flow cell surface }\end{array}$} & \multirow{4}{*}{$\begin{array}{l}\text { Optical detection of } \\
\text { fluorescent emission from } \\
\text { nucleotide incorporation }\end{array}$} & \multirow{4}{*}{$\begin{array}{l}\text { Single gene, genome } \\
\text { sequencing } \\
\text { Single gene; genome and } \\
\text { transcriptome sequencing }\end{array}$} \\
\hline & & & & & & \\
\hline Hiseq 2500 & $\begin{array}{l}\sim 125-250 \\
\sim 150\end{array}$ & $\begin{array}{l}\sim 7-60 \mathrm{~h} \\
1-3 \text { days }\end{array}$ & & & & \\
\hline Hiseq 4000 & $\sim 150$ & 1-3 days & & & & \\
\hline \multicolumn{7}{|l|}{ Pacific Bioscience } \\
\hline PacBio RS SMRT & 20,000 & $0.5-4 \mathrm{~h}$ & $\begin{array}{l}\text { Single molecule } \\
\text { real time } \\
\text { sequencing by } \\
\text { synthesis }\end{array}$ & Not required & $\begin{array}{l}\text { Optical detection of } \\
\text { fluorescent emission from } \\
\text { labelled nucleotide } \\
\text { incorporation }\end{array}$ & $\begin{array}{l}\text { Single gene; genome and } \\
\text { transcriptome sequencing }\end{array}$ \\
\hline
\end{tabular}

\subsection{Metaproteomics}

Metraproteomics provides a direct measure of proteins present in an environmental sample such as soil, offering information about the functional roles of soil microorganism, such as biogeochemical processes, degradation, or bioremediation processes (Bastida et al., 2012,
Chourey et al., 2010). VerBerkmoes et al. (2009) proposed proteogenomics as an important tool for studying the physiology, ecology and evolution of microbial populations, communities and consortia in several environments as a means to connect a microbial species with its function. This approach is important since it combines metagenomics and proteomics and provides for 
the verification of metagenomics studies by protein data. However, it is necessary to considerer that the databases for soil protein identification are still incomplete. Nevertheless, numerous metaproteomics studies have revealed the diversity of proteinsthat are expressed by the interactions between plants and soil microbial communities. Recently, Lin et al. (2013) compared a metaproteomics profile of rhizosphere of ratoon sugarcane and plant sugarcane. The results revealed that ratoon sugarcane induced significant changes in the soil enzyme activities, the catabolic diversity of microbial community, and the expression level of soil proteins originated from the plants, microbes and fauna. This study also reported that $24.77 \%$ of soil proteins are derived from bacteria and most of the up-regulated expression of microbial proteins were involved to membrane transport and signal transduction. Similarly, Wu et al. (2011) realized a comparative metaproteomics analysis for determining the changes on soil protein abundance under consecutive monoculture of herb Rehmannia glutinosa. The results shown the identification proteins of plants, bacteria and fungi mainly involved in the carbohydrate and energy metabolism, aminoacids metabolism, stress/defense response. However, compared with Lin et al. (2013) study, lower percentages (11.65\%) of proteins derived from bacteria were found, mainly involved in signal transduction. Moreover, Moretti et al. (2012) demonstrated that the rhizosphere of lettuce (Lactuca sativa) produced higher amount of proteins related with virulence determinants, energy metabolism, stress/defense response in presence of pathogenic strain of $\mathrm{Fu}$ sarium oxysporum which could be related with the interaction the microbial consortium associated to this fungus.

\subsection{Metatranscriptomics}

Metatranscriptomics involves the characterization of a set of messenger RNA (mRNA) (transcripts) produced in all cells, which would provide insight into the metabolic processes of a microbial community (Simon and Daniel, 2011; de Menezes et al., 2012). Consequently, metatranscriptomics analysis has the potential to discover novel genes and functions, allowing identification of active community members in both bulk and rhizosphere soils, and to correlate them with their metabolic activities (Kim et al., 2014). However, metatranscriptomic approaches have not been widely used in the rhizosphere, probably due to the instability of mRNAs and difficulties in their extraction from complex ecosystems. Among the more notable methodological challenges are their short half-lives, difficulties in the separation of mRNA from other RNA types (i.e.tRNA, rRNA miRNA) and interference from humic compounds that co-extract with nucleic acids from soil (Simon and Daniel, 2011). In addition, few studies have applied metagenomics, metaproteomics and metatranscriptomics due also to the difficulties and expense related to simultaneous extraction of nucleic acids and proteins from soil samples (Table 2). Moreover, the majority of studies in bulk and rhizosphere soils are mainly focused on bacteria, demonstrating the need for further studies to obtain further insights into the molecular ecology of other microorganisms present in rhizosphere microbiome, such as fungi, archaea, microalgae, protozoa, etc.

In order to better understand microbial genomes and characterize bacterial phylogeny, the Genomic Encyclopedia of Bacteria and Archaea Project (GEBA Project) was initiated in 2007. 
This project is lead by the US Department of Energy (USDOE)Joint Genome Institute, Institute of California Davis, USA, and German Collection of Microorganisms and Cell Cultures, Germany (DSMZ) (Wu et al., 2009). Currently, 200 bacterial genomes have been sequenced. The principal objectives of this project are to improve identification of proteins families, and to identify novel genes and undescribed organisms (http:// goo.gl/FNpdwv revised in January, 2015). GEBA Project have other cooperative projects, such as GEBA-type strain, GEBA-RNB (Root Noduling Bacteria), and GEBA-MDM (Microbial Dark Matter). The main objective of GEBA-type strain project is to find novel functions of protein families, and thus, discovery of natural products. On the other hand, GEBA-RNB project is based in sequencing 100 symbiotic bacterial strains isolated from different soils around the world. This project can improve our understanding of the endosymbiotic relations between bacteria and roots, and nitrogen fixation. The GEBA-MDM project objective is to use single-cell genomics to explore uncultured bacteria and archaea that GEBA project does not include. Hence, the discovery of novel genomes by this project will improve phylogeny and the evolution of bacterial and archaeal domains (Rinke et al., 2013).

Finally, the Pacific Biosciences single-molecule real-time (PacBio RS SMRT) sequencer is a third-generation sequencing technology (Niedringhaus et al., 2011). It is noteworthy that the PacBio RS SMRT has been applied to genome sequencing of Streptomyces sp. strain $\mathrm{Mg}$, a soil bacterium can cause lysis and degradation of $\mathrm{Ba}$ cillus subtilis (Hoefler et al., 2013). Moreover, it may be a suitable platform for longer sequencing reads of 16S rRNA genes from environmental samples; according to Mosher et al. (2013), this approach could provide more information about microbial taxonomy and the phylogeny of microbe inhabitants of the rhizosphere.

Table 2. Applications and limitations of post-genomic techniques currently used in soil Microbiology

\begin{tabular}{|c|c|c|c|c|}
\hline Technique & Target & Application & Limitations & References \\
\hline Metagenomics & DNA & $\begin{array}{l}\text { Biodiversity and gene } \\
\text { quantification }\end{array}$ & $\begin{array}{l}\text { - DNA is extracted from all cells (active and } \\
\text { non-actives) } \\
\text { - Limited to the dominant members of the } \\
\text { microbial community of soils }\end{array}$ & $\begin{array}{l}\text { Bastida et al., 2009; Simon and } \\
\text { Daniel, 2011; van Elsas and } \\
\text { Boersma, 2011 }\end{array}$ \\
\hline Metatranscriptomics & RNA & $\begin{array}{l}\text { Biodiversity and gene } \\
\text { expression }\end{array}$ & $\begin{array}{l}\text {-Liability of RNA } \\
\text { - Interference by soil humic compounds }\end{array}$ & $\begin{array}{l}\text { Simon and Daniel, 2011; } \\
\text { Bastida et al., } 2009\end{array}$ \\
\hline Metaproteomics & PROTEINS & $\begin{array}{l}\text { Gene functions, } \\
\text { activitiesand metabolic } \\
\text { functions }\end{array}$ & $\begin{array}{l}\text {-Intracellular proteins-N only } 4 \% \text { of total } \mathrm{N} \\
\text { - Prevalence of extracellular stabilized proteins- } \\
\mathrm{N} \text { not involved in the microbial activity at } \\
\text { sampling but expression of past event } \\
\text { - Strongly adsorbed onto soil minerals or humic } \\
\text { colloids }\end{array}$ & $\begin{array}{l}\text { Simon and Daniel, 2011; } \\
\text { Bastida et al., 2009; Nannipieri, } \\
2006\end{array}$ \\
\hline
\end{tabular}




\section{Conclusions and perspectives}

Rhizospheres are complex and dynamic habitats characterized by high microbial activities. The diversities in different zones in the rhizosphere can be influenced by plant-bacteria and bacteria-bacteria interactions regulated by communication, competition along root zones, plant growth stage, and plant species. The advances in soil molecular and post-genomic techniques will continue to improve our understanding of the compositions and activities of soil microbial communities, to target the rare or low abundance bacterial populations in the rhizosphere, and to predict in situ responses, activities, and growth of bacterial communities. Until very recently, few studies of soil and rhizosphere soils have been performed using metagenomics, metaproteomics and metatranscriptomics; these approaches may be limited by difficulties of extractions and purification of nucleic acids and proteins from complex environmental samples. Advances in nucleotide and protein sequencing techniques might allow lower costs, making them more accessible, expanding libraries DNA or database to continue uncovering more genomes and functions of microbiota of bulk and rhizosphere soils. Being an interesting approach for improving strategies to select indigenous potentially beneficial bacterial strains that may function as biofertilizers or bioprotectors, to understand the importance of the rhizosphere microbiome in promoting plant health and, to study the mechanisms of plant impacts (exudates) on the rhizosphere soil microbiome (Bakker et al., 2013).Therefore, collaborative efforts are needed for future biotechnological developments allowing the establishment of adequate and efficient strate- gies of rhizosphere management, benefitting the yield and sustainability of agricultural systems.

\section{Acknowledgments}

This work was financed by Fondecyt Grants no. 1120505 and 1141247, and International Cooperation Grants Conicyt-USA (USA2013-0010) and Conicyt-MEC (no. 80140015). L. Lagos acknowledges Conicyt Doctor Scholarship no. 21120698. F. Maruyama thanks the support by JSPS KAKENHI Grant no. 25670776, 25713060, 24117508.

\section{References}

Arenella. M., Giagnoni, L., Masciandaro, G, Ceccanti, B., Nannipieri, P., Renella, G. 2014 Interactions between proteins and humic substances affect protein identification by mass spectrometry. Biol. Fertil. Soils. 50, 447-454.

Ascher, J., Ceccherini, M.T., Chen, Y., Murrell, J.C., Pietramellara, G., Smalla, K. 2011. Molecular Techniques. In: Handbook of Soil Sciences: Properties and Processes, Second Edition by CRC Press pp. 1-38.

Avis, T.J., Gravel, V., Antoun, H., Tweddell, R.J. 2008. Multifaceted beneficial effects of rhizosphere microorganisms on plant health and productivity. Soil. Biol. Biochem. 40, 1733-1740.

Babalola, O.O. 2010. Beneficial bacteria of agricultural importance. Biotechnol. Lett. 32, 1559-1570.

Bais, H.P., Park, S.W., Weir, T.L., Callaway, R.M., Vivanco, J.M. 2004. How plants communicate using the underground information superhighway. Trends Plant Sci. 9, 26-32.

Bakker, P., Berendsen, R., Doornbos, R., Wintermans, P., Pieterse, C. 2013. The rhizosphere revisited: root microbiomics. Front. Plant Sci.165, 1-7. 
Barret, M., Morrissey, J.P., O’Gara, F. 2011. Functional genomics analysis of plant growth-promoting rhizobacterial traits involved in rhizosphere competence. Biol. Fert. Soils. 47, 729-743.

Barriuso, J., Ramos Solano, B., Fray, R.G., Cámara, M., Hartmann, A., Gutiérrez Mañero, F.J. 2008. Transgenic tomato plants alter quorum sensing in plant growth-promoting rhizobacteria. Plant Biotech. J. 6, 442-452.

Bastida, F., Algora, C., Hernández, T., García, C. 2012. Feasibility of a cell separation-proteomic based method for soils with different edaphic properties and microbial biomass. Soil. Biol. Biochem. 45, 136-138.

Bastida, F., Moreno, J.L., Nicolas, C., Hernandez, T., Garcia, C. 2009. Soil metaproteomics: a review of an emerging environmental science. Significance, methodology and perspectives. Eur. J. Soil Sci. 60, 845-859.

Berlec, A. 2012. Novel techniques and findings in the study of plant microbiota: search for plant probiotics. Plant Sci.193, 96-102.

Bertin, C., Yang, X., Weston, L. 2003. The role of root exudates and allelochemicals in the rhizosphere. Plant Soil. 256, 67-83.

Bestel-Corre, G., Dumas-Gaudot, E., Gianinazzi, S. 2004. Proteomics as a tool to monitor plant-microbe endosymbioses in the rhizosphere. Mycorrhiza. $14,1-10$.

Brown, M.M., Friez, M.J., Lovell, C.R. 2003. Expression of nifH genes by diazotrophic bacteria in the rhizosphere of short form Spartina alterniflora. FEMS Microbiol. Ecol. 43, 411-417.

Bulgarelli. D., Schlaeppi, K., Spaepen S, van Themaat, E.V.L., Schulze-Lefer,t P. 2013. Structure and functions of the bacterial microbiota of plants. Annu. Rev. Plant Biol. 64, 807-838.
Capdevila, S., Martínez-Granero, F.M., Sanchez-Contreras, M., Rivilla R., Martin, M. 2004. Analysis of Pseudomonas fluorescens F113 genes implicated in flagellar filament synthesis and their role in competitive root colonization. Microbiology. 150, 3889-3897.

Cha, C., Gao, P., Chen, Y.C., Shaw, P.D., Farrand, S.K. 1998. Production of acyl-homoserine lactone quorum-sensing signals by gram-negative plant-associated bacteria. Mol. Plant Microbe Interact. 11, 1119-1129.

Chaparro, J.M., Sheflin, A.M., Manter, D.K., Vivanco, J.M. 2012. Manipulating the soil microbiome to increase soil health and plant fertility. Biol. Fert. Soils. 48, 489-499.

Chen, J.S., Zhu, R.F., Zhang, Y.X. 2013. The effect of nitrogen addition on seed yield and yield components of Leymus chinensis in Songnen Plain, China. J. Soil Sci. Plant Nutr. 13, 239-339.

Cheng, Z., McConkey, B.J., Glick, B.R. 2010. Proteomic studies of plant-bacterial interactions. Soil. Biol. Biochem. 42, 1673-1684.

Chourey, K., Jansson,J., VerBerkmoes, N.C., Shah, M., Chavarria, K.L., Tom, L.M., Brodie, E.L., Hettich, R.L. 2010. Direct cellular lysis/protein extraction protocol for soil metaproteomics. J. Proteome Res. 9, 6615-6622.

Compant, S., Duffy, B., Nowak, J., Cle, C. 2005. Use of plant growth-promoting bacteria for biocontrol of plant diseases : principles, mechanisms of action, and future prospects. Appl. Environ. Microbiol. 71, 4951-4959.

Curtis, T.P., Sloan, W.T. 2005. Exploring microbial diversity: a vast below. Science. 309, 1331-1333.

Damon, C., Lehembre, F., Oger-Desfeux, C., Luis, P., Ranger, J., Fraissinet-Tachet, L., Marmeisse, R. 2012. Metatranscriptomics reveals the diversity of genes expressed by eukaryotes in forest soils. PloS one. $7,1-12$. 
de Campos, S.B., Youn, J.W., Farina, R., Jaenicke S, Jünemann, S., Szczepanowski, R., Beneduzi. A., Vargas, L.K., Goesmann, A., Wendisch, V.F., Passaglia, L.M.P. 2013. Changes in root bacterial communities associated to two different development stages of canola (Brassica napus var. oleifera) evaluated through next-generation sequencing technology. Microb. Ecol. 65, 593-601.

deMenezes, A., Clipson, N., Doyle, E., 2012. Comparative metatranscriptomics reveals widespread community responses during phenanthrene degradation in soil. Environ. Microbiol. 14, 2577-2588.

DeAngelis, K.M., Firestone, M.K., Lindow, S.E. 2007. Sensitive whole-cell biosensor suitable for detecting a variety of $\mathrm{N}$-acyl homoserine lactones in intact rhizosphere microbial communities. Appl. Environ. Microbiol.73, 3724-3727.

Decoste, N.J., Gadkar, V.J., Filion, M. 2010. Verticilliumdahliae alters Pseudomonas spp. populations and $\mathrm{HCN}$ gene expression in the rhizosphere of strawberry. Can. J. Microbiol. 56, 906-915.

Deepak, S., Kottapalli, K., Rakwal, R., Oros, G., Rangappa, K., Iwahashi, H., Masuo, Y., Agrawal, G. 2007. Real-Time PCR: revolutionizing detection and expression analysis of genes. Curr. Genomics 8, 234-251.

Doornbos, R., van Loon L.C., Bakker, P.A.H.M. 2012. Impact of root exudates and plant defense signaling on bacterial communities in the rhizosphere: a review. Agron. Sustain. Dev. 32, 227-243.

Elasri, M., Delorme, S., Lemanceau, P., Stewart, G., Laue, B., Glickmann, E., Oger, P.M., Dessaux, Y. 2001. Acyl-Homoserine lactone production is more common among plant-associated Pseudomonas spp. than among soilbornem Pseudomonas spp. Appl. Environ. Microbiol. 67, 1198-1209

Fauren, D., Vereecke, D., Leveau, J.H.J. 2009. Molecular communication in the rhizosphere. Plant Soil. 321, 279-303.
Germaine, K., Keogh, E., Garcia-Cabellos, G., Borremans, B., Lelie, D., Barac, T., Oeyen, L., Vangronsveld, J., Moore, F.P., Moore, E.R.B., Campbell, C.D., Ryan, D., Dowling, D.N. 2004. Colonization of poplar trees by gfp expressing bacterial endophytes. FEMS Microbiol. Ecol. 48, 109-118.

Götz, M., Gomes, N.C.M., Dratwinski, A., Costa, R., Berg, G., Peixoto, R., Mendonça-Hagler, L., Smalla, K., 2006. Survival of gfp-tagged antagonistic bacteria in the rhizosphere of tomato plants and their effects on the indigenous bacterial community. FEMS Microbiol. Ecol. 56, 207-218.

Handelsman, J., Rondon, M.R., Brady, S.F., Clardy, J., Goodman, R.M. 1998. Molecular biological access to the chemistry of unknown soil microbes: a new frontier for natural products. Chem. Biol. $5,245-249$.

Heeb, S., Haas, D. 2001. Regulatory roles of the GacS/GacA two-component system in plant-associated and other gram-negative bacteria. Mol. Plant Microbe Interact. 14, 1351-1363.

Hill, G.T., Mitkowski, N., Aldrich-Wolfe, L., Emele, L.R., Jurkonie, D.D., Ficke, Maldonado-Ramirez, S., Lynch, S.T., Nelson, E.B. 2000. Methods for assessing the composition and diversity of soil microbial communities. Applied Soil Ecology. $15,25-36$.

Hinsinger, P., Bengough, A.G., Vetterlein, D., Young, I.M. 2009. Rhizosphere: biophysics, biogeochemistry and ecological relevance. Plant Soil. 321, 117-152.

Hirsch, A.M., Bauer, W.D., Bird, D.M., Cullimore, J., Tyler, B., Yoder, J.I. 2003. Molecular signals and receptors: controlling rhizosphere interactions between plants and other organisms. Ecology. 84, 858-868.

Hirsch, P.R., Mauchline, T.H., Clark, I.M. 2010. Culture-independent molecular techniques for soil microbial ecology. Soil. Biol. Biochem. 42, 878-887. 
Hoefler,C., Konganti,K.,Straighta, P.D. 2013. De novo assembly of the Streptomyces sp. strain Mg1 genome using PACBIO Single-Molecule Sequencing. Genome Announc. 1, e00535-13.

Jaeger, C.H., Lindow, S.E., Miller, W., Clark, E., Firestone, M.K. 1999. Mapping of sugar and amino acid availability in soil around roots with bacterial sensors of sucrose and tryptophan. Appl. Environ. Microbiol. 65, 2685-2690.

Jorquera, M.A., Inostroza, N.G., Lagos, L.M., Barra, P.J., Marileo, L.G, Rilling, J.I., Campos, D.C., Crowley, D.E., Richardson, A.E., Mora, M.L. 2014. Bacterial community structure and detection of putative plant growth-promoting rhizobacteria associated with plants grown in Chilean agro-ecosystems and undisturbed ecosystems. Biol. Fert. Soils. 50, 1141-1153.

Jorquera, M.A., Saavedra, N., Maruyama, F., Richardson, A.E., Crowley, D.E., Catrilef, R.C., Henriquez, E.J., Mora, M.L. 2013. Phytate addition to soil induces changes in the prevalence and expression of Bacillus $\beta$-propeller phytase genes in the rhizosphere. FEMS Microbiol. Ecol. 83,352-360.

Kang, Y.J., Cheng, J., Mei, L.J., Hu, J., Piao, Z., Yin, S.X. 2010. Multiple copies of 16S rRNA gene affect the restriction patterns and DGGE profile revealed by analysis of genome database. Microbiology. 79, 655-662.

Karlsson, A.E., Johansson, T., Bengtson, P. 2012. Archaeal abundance in relation to root and fungal exudation rates. FEMS Microbiol. Ecol. 80, 305-311.

Keiblinger, K.M., Wilhartitz, I.C., Schneider, T., Roschitzki, B., Schmid, E., Eberl, L., Riedel, K., Zechmeister-Boltenstern, S. 2012. Soil metaproteomics comparative evaluation of protein extraction protocols. Soil. Biol. Biochem. 54, 14-24.
Kim Y, Wegner C-E, Liesack W. 2014. Soil metatrascriptomic. In Nannipieri P, Pietramellara G, Renella G (Eds) Omics in Soil Science. Caister Academic Press, Norfolk, UK, pp 63-93.

Lagos, L., Navarrete, O., Maruyama, F., Crowley, D.E., Cid, F., Mora, M.L., Jorquera, M.A. 2014. Bacterial community structures in rhizosphere microsites of ryegrass (Lolium perenne var. Nui) as revealed by pyrosequencing. Biol. Fert. Soils. 50, 1253-1266.

Lambers, H., Mougel, C., Jaillard, B., Hinsinger, P. 2009. Plant-microbe-soil interactions in the rhizosphere: an evolutionary perspective. Plant Soil. 321, 83-115.

Lin,W., Wu, L., Lin, S., Zhang, A., Zhou, M., Lin, R., Wang, H., Chen, J., Zhang, Z., Lin, R. 2013. Metaproteomic analysis of ratoon sugarcane rhizospheric soil. BMC Microbiol.13, 135-148.

Lugtenberg, B., Kamilova, F. 2009. Plant-growthpromoting rhizobacteria. Annu. Rev. Microbiol. 63, 541-556.

Lugtenberg, B.J., Kravchenko, L.V., Simons, M. 1999. Tomato seed and root exudate sugars: composition, utilization by Pseudomonas biocontrol strains and role in rhizosphere colonization. Environ. Microbiol. 1, 439-446.

Lugtenberg, B.J.J., Dekkers, L., Bloemberg, G.V. 2001. Molecular determinants of rhizosphere colonization by Pseudomonas. Ann. Rev. Phytopathol. 39, 461-490.

Malik, M.A., Khan, K.S., Marschner, P., Fayyas-ulHassan. 2013. Microbial biomass, nutrient availability and nutrient uptake by wheat in two soils with organic amendments. J. Soil Sci. Plant Nutr. 13, 955-966.

Marschner, P., Crowley D., Hong Yang, C. 2004. Development of specific rhizosphere bacterial communities in relation to plant species, nutrition and soil type. Plant Soil. 261, 199-208. 
Marschner, P., Crowley, D., Rengel, Z. 2011. Rhizosphere interactions between microorganisms and plants govern iron and phosphorus acquisition along the root axis-model and research methods. Soil. Biol. Biochem. 43, 883-894.

Martínez-Granero F., Rivilla, R., Martín, M., 2006. Rhizosphere selection of highly motile phenotypic variants of Pseudomonas fluorescens with enhanced competitive colonization ability. Appl. Environ. Microbiol. 72, 3429-3434.

Mavrodi, O.V., Mavrodi, D.V., Thomashow, L.S., Weller, D.M. 2007. Quantification of 2, 4-diacetylphloroglucinol-producing Pseudomonas fluorescens strains in the plant rhizosphere by real-time PCR. Appl. Environ. Microbiol. 73, 5531-5538.

Mendes, R., Kruijt, M., de Bruijn, I., Dekkers, E., van der Voort, M., Schneider, J.H.M., Piceno, Y.M., DeSantis, T.Z., Andersen, G.L., Bakker, P., Raaijmakers, J. 2011. Deciphering the rhizosphere microbiome. Science. 1097, 1097-1100.

Moretti, M., Minerdi, D., Gehrig, P., Garibaldi, A., Gullino, M.L., Riedel, K. 2012. A bacterial-fungal metaproteomic analysis enlightens an intriguing multicomponent interaction in the rhizosphere of Lactuca sativa. Proteome Res. 11, 2061-2077.

Morrisey J.P., Dow J.M., Mark G.L., O'Gara, F. 2004. Are microbes at the root of a solution to world food production?. EMBO Rep. 5, 922-926.

Mosher, J.J., Bernberg, E.L., Shevchenko,O., Kan, J., Kaplan, L.A. 2013. Efficacy of a 3rd generation high-throughput sequencing platform for analyses of 16S rRNA genes from environmental samples. J. Microbiol. Methods. 95,175-181.

Myrold, D.D., Nannipieri, P. 2014. Classical Techniques versus Omics Approaches. In Nannipieri P, Pietramellara G, Renella G (Eds) Omics in soil Science. Caster Academic Press, Norfolk. UK, pp 179-187.
Nannipieri, P. 2006. Role of stabilised enzymes in microbial ecology and enzyme extraction from soil with potential applications in soil proteomics. In: Nannipieri, P., Smalla, K. (Eds.), Nucleic Acids and Proteins in Soil. Springer, Heidelberg, pp. 75-94.

Nannipieri, P., Ascher, J., Ceccherini, M.T., Guerri, G., G. Renella, A., Pietramellara, G. 2008. Recent Advances in Functional Genomics and Proteomics of Plant Associated Microbes. In: Nautiyal, C.S., Dion, P. (Eds.), Molecular Mechanisms of Plant and Microbe Coexistence Soil Biology Vol.15. Springer Berlin Heidelberg, pp. 215-241.

Niedringhaus, T.P., Milanova, D., Kerby, M.B., Snyder, M.P., Barron, A.E. 2011. Landscape of nextgeneration sequencing technologies. Anal. Chem. 83, 4327-4341.

Nguyen, T.-T., Fuentes, S., Marschner, P. 2013. Effect of incorporated or mulched compost on leaf nutrient concentrations and performance of Vitis vinifera cv. Merlot. J. Soil Sci. Plant Nutr. 13,485-497.

Pava-Ripoll, M., Angelini, C., Fang, W., Wang, S., Posada, F.J., St Leger, R. 2011. The rhizospherecompetent entomopathogen Metarhizium anisopliae expresses a specific subset of genes in plant root exudate. Microbiology. 157, 47-55.

Peck, M.C., Fisher, R.F., Long, S.R. 2006. Diverse flavonoids stimulate NodD1 binding to nod gene promoters in Sinorhizo biummeliloti. J. Bacteriol. $188,5417-5427$.

Peiffer, J.A., Spor, A., Koren, O., Jin, Z., Tringe, S.G., Dangl, J.L., Buckler, E.S., Ley, R.E. 2013. Diversity and heritability of the maize rhizosphere microbiome under field conditions. Proc. Natl. Acad. Sci. U.S.A. 110, 6548-6553.

Pii, Y., Mimmo, T., Tomasi, N., Terzano, R., Cesco, S., Crecchio, C. 2015. Microbial interactions in the rhizosphere: beneficial influences of plant growth-promoting rhizobacteria on nutrient acquisition process: a review. Biol. Fertil. Soils. 51, 403-415 
Pires A.C.C., Cleary D.F.R., Almeida, A. 2012. Denaturing gradient gel electrophoresis and barcoded pyrosequencing reveal unprecedented archaeal diversity in mangrove sediment and rhizosphere samples. Appl. Environ. Microbiol. 78, $5520-5528$.

Pisa, G., Magnani, G.S., Weber, H., Souza, E.M., Faoro, H., Monteiro, R., Daros, E., Baura, V., Bespalhok, J.P., Pedrosa, F.O., Cruz, L.M. 2011. Diversity of $16 \mathrm{~S}$ rRNA genes from bacteria of sugarcane rhizosphere soil. Braz. J. Med. Biol. Res. 44, 1215-1221.

Raaijmaker, J.M.,van der Sluis,L., Koster, M., Bakker, P.A.H.M., Weisbeek, P.J., Schippers, B. 1995. Utilization of heterologous siderophores and rhiozsphere competence of fluorescent Pseudomonas spp. Can. J. Microbiol. 41, 126-135.

Raaijmakers, J.M., Paulitz, T.C. 2009. The rhizosphere : a playground and battlefield for soilborne pathogens and beneficial microorganisms. Plant Soil. 321, 341-361.

Raina, S., De Vizio, D., Odell, M., Clements, M., Vanhulle, S., Keshavarz, T., 2009. Microbial quorum sensing: a tool or a target for antimicrobial therapy?. Biotechnol. Appl. Biochem. 54, 65-84.

Rinke, C., Schwientek, P., Sczyrba, A., Ivanova, N.N., Anderson, I.J., Cheng J-F., Darling, A., Malfatti, S., Swan, B.K., Gies, E.A., Dodsworth, J.A., Hedlund, B.P., Tsiamis, G., Sievert,,S.M., Liu,W-T., Eisen, J.A., Hallam, S.J., Kyrpides, N.C., Stepanauskas, R., Rubin, E.M., Hugenholtz, P., Woyke, T. 2013. Insights into the phylogeny and coding potential of microbial dark matter. Nature. 499,431-437.

Rovira, A. 1965. Interactions between plant roots and soil microorganisms. Annu. Rev. Microbiol. 19, 241-266.

Schmidt, P.A., Bálint, M.,Greshake, B.,Bandow, C., Römbke, J., Schmitt, I. 2013. Llumina metabarcoding of a soil fungal community. Soil Biol. Biochem. 65, 128-132.
Shidore, T., Dinse, T., Ohrlein, J., Becker, A., Reinhold-Hurek, B. 2012. Transcriptomic analysis of responses to exudates reveal genes required for rhizosphere competence of the endophyte Azoarcus sp. strain BH72. Environ. Microbiol. 14, 2775-2787.

Simon, C., Daniel, R. 2011. Metagenomics analyses: past and future trends. Appl. Environ. Microbiol.77, 1153-1161.

Singh, J.S., Pandey, V.C., Singh, D.P. 2011. Efficient soil microorganisms: a new dimension for sustainable agriculture and environmental development. Agric. Ecosyst. Environ. 140, 339-353.

Smalla, K., Oros-Sichler, M., Milling, A., Heuer, H., Baumgarte, S., Becker, R., Neuber, G., Kropf, S., Ulrich, A., Tebbe, C.C. 2007. Bacterial diversity of soils assessed by DGGE, T-RFLP and SSCP fingerprints of PCR-amplified 16S rRNA gene fragments: do the different methods provide similar results?. J. Microbiol. Methods. 69, 470-479.

Sørensen, J., Haubjerg Nicolaisen, M., Ron, E., Simonet, P. 2009. Molecular tools in rhizosphere Microbiology from single-cell to whole-community analysis. Plant Soil. 321, 483-512.

Sun, J., Zhang, Q., Zhou, J., Wei, Q. 2014. Illumina amplicon sequencing of $16 \mathrm{~S}$ rRNA tag reveals bacterial community development in the rhizosphere of apple nurseries at a replant disease site and a new planting site. PLoS ONE. 9, e111744.

Tokala, R.K., Strap, J.L., Jung, C.M., Crawford, D.L., Salove, M.H., Deobald, L.A. 2002. Novel plant-microbe rhizosphere interaction involving Streptomyces lydicus WYEC108 and the pea plant (Pisum sativum). Appl. Environ. Microbiol. 68, 2161-2171.

Torsvik, V., Ovreas, L., Thingstad, T.F. 2002. Prokaryotic diversity: Magnitude, dynamics, and controlling factors. Science. 296, 1064-1066. 
Tremblay, J., Déziel, E. 2010. Gene expression in Pseudomonas aeruginosa swarming motility. BMC Genomics. 11, 587- 592.

Ulrich, L.E., Koonin, E.V., Zhulin, I.B. 2005. Onecomponent systems dominate signal transduction in prokaryotes. Trends Microbiol. 13, 52-56.

Unno, T. 2014. Bioinformatic suggestions on miseq-based microbial community analysis. J. Mol. Microbiol. Biotechnol. doi: 10.4014/ jmb.1409.09057.

Uren, N.C. 2000. Functions of compounds released into the rhizosphere by soil-grown plants. In: in the rhizosphere: biochemistry and organic substances at the soil- plant interface. Eds. R. Pinton, Z. Varanini and P. Nannipieri. Marcel Dekker, Inc, New York. pp. 19-40.

Uroz, S., Buée, M.,Murat, C., Frey-Klett, P.,Martin, F. 2010. Pyrosequencing reveals a contrasted bacterial diversity between oak rhizosphere and surrounding soil. Environ. Microbiol. Rep. 2, 281-288.

vanElsas, J.D., Boerma, F.G.H. 2011. A review of molecular methods to study the microbiota of soil and the mycosphere. Eur. J. Soil Biol. 47, 77-87.

vanPuyvelde, S., Cloots, L., Engelen, K., Das, F., Marchal, K., Vanderleyden, J., Spaepen, S. 2011. Transcriptome analysis of the rhizosphere bacterium Azospirillum brasilense reveals an extensive auxin response. Microb. Ecol. 61, 723-728.

VerBerkmoes, N.C., Denef, V.J., Hettich, R.L., Banfiel, J.F. 2009. Systems Biology: Functional analysis of natural microbial consortia using community proteomics. Nat. Rev. Microbiol. 7, 196-205.

Větrovský, T., Baldrian, P. 2013. The variability of the 16S rRNA gene in bacterial genomes and its consequences for bacterial community analyses. PLoS ONE. 8, 1-10.
Ward, N.L., Challacombe, J.F., Janssen, P.H., Henrissat, B., Coutinho, P.M., Wu, M. 2009. Three genomes from the phylum Acidobacteria provide insight into the lifestyles of these microorganisms in soils. Appl. Environ. Microbiol. 75, 2046-2056.

Watt, M., Silk, W.K., Passioura, J.B. 2006. Rates of root and organism growth, soil conditions, and temporal and spatial development of the rhizosphere. Ann. Bot. 97, 839-855.

Weinert, N., Piceno, Y., Ding, G.C., Meincke, R., Heuer, H., Berg, G., Schloter, M., Andersen, G., Smalla, K. 2011. PhyloChip hybridization uncovered an enormous bacterial diversity in the rhizosphere of different potato cultivars: many common and few cultivar-dependent taxa. FEMS Microbiol. Ecol. 75, 497-506.

Weisskopf, L., Abou-Mansour, E., Fromin, N., Tomasi, N., Santelia, D., Edelkott, I., Neumann, G., Aragno, M., Tabacchi, R., Martinoia, E. 2006. White lupin has developed a complex strategy to limit microbial degradation of secreted citrate required for phosphate acquisition. Plant Cell Environ. 29, 919-927.

Weyens, N., Boulet, J., Adriaensen, D., Timmermans, J.P., Prinsen, E., Oevelen, S., D'Haen, J., Smeets, K., Lelie, D., Taghavi, S., Vangronsveld, J. 2012. Contrasting colonization and plant growth promoting capacity between wild type and a GFPderative of the endophyte Pseudomonas putida W619 in hybrid poplar. Plant Soil. 356, 217-230.

Wilkins, M.R., Sanchez, J.C., Gooley, A., Appel, R.D., Humphery-Smith, I., Hochstrasser, D.F., Williams, K.L. 1995. Progress with proteome projects: Why all proteins expressed by genome should be identified and how to do it. Biotechnol. Genet. Eng. Rev. 13, 19-50.

Wu, D., Hugenholtz, P., Mavromatis, K., Pukall, R., Dalin, E., Ivanova, N.N., Kunin, V., Goodwin, L., Wu, M., Tindall, B.J., Hooper, J.D., Pati, A., Lykidis, A., Spring, S., Anderson, I.J., 
D'haeseleer, P., Zemla, A., Singer, M., Lapidus, A., Nolan, M., Copeland, A., Han, C., Chen, F., Cheng J-F., Lucas, S., Kerfeld, C., Lang, E., Gronow, S., Chain, P., Bruce, D., Rubin, E.M., Kyrpides, N.C., Klenk H-P., Eisen, J.A. 2009. A phylogeny-driven genomic encyclopaedia of Bacteria and Archaea. Nature. 462, 1056-1060.

Wu, L., Wang, H., Zhang, Z., Lin, R., Zhang, Z., Lin, W. 2011. Comparative metaproteomic analysis on consecutively Rehmannia glutinosa monocultured rhizosphere soil. PloS One. 6, 1-12.
Xu, L., Ravnskov, S., Larsen, J., Nilsson, R.H., Nicolaisen, M. 2012. Soil fungal community structure along a soil health gradient in pea fields examined using deep amplicon sequencing. Soil Biol. Biochem. 46, 26-32.

Yang, C., Hamel, C., Gan, Y., Vujanovic, V. 2012. Pyrosequencing reveals how pulses influence rhizobacterial communities with feedback on wheat growth in the semiarid Prairie. Plant Soil. 367, 493-505.

Yang, C.H., Crowley, D.E. 2000. Rhizosphere microbial community structure in relation to root location and plant iron nutritional status. Appl. Environ. Microbiol. 66, 345-51. 